\title{
SOME PSYCHODIDAE (DIPTERA) FROM ATLANTIC FOREST IN SOUTH-EASTERN BRAZIL, WITH DESCRIPTIONS OF Trichomyia dolichopogon sp. NOV. AND Trichomyia riodocensis sp. NOV.
}

\author{
ALEXANDER, B., ${ }^{1}$ FREITAS, J. M. ${ }^{1}$ and QUATE, L. W. ${ }^{2}$ \\ ${ }^{1}$ Departamento de Parasitologia, Instituto de Ciências Biológicas, Universidade Federal de Minas Gerais, \\ C.P. 486, CEP 31270-901, Belo Horizonte, MG, Brazil \\ ${ }^{2}$ Natural History Museum of Los Angeles County, 900, Exposition Boulevard, \\ Los Angeles, 90007, California, USA \\ Correspondence to: Bruce Alexander, Centro de Pesquisas René Rachou (MS-Fiocruz), Av. Augusto de Lima, 1715, \\ C.P. 1743, CEP 30190-002, Barro Preto, Belo Horizonte, MG, Brazil, e-mail: bruce @ netra.cpqrr.fiocruz.br \\ Received May 28, 1999 - Accepted March 8, 2000 - Distributed August 31, 2001
}

(With 3 figures)

\begin{abstract}
The family Psychodidae includes the medically important phlebotomine sand flies and four other subfamilies that have been little studied in the Neotropics. The authors here report the results of a trip to collect psychodids in Parque Estadual do Rio Doce, a national park in Minas Gerais that contains one of the largest surviving areas of Atlantic Forest in Brazil. Collections made by Malaise and CDC light traps as well as from diurnal resting sites included 15 species of Psychodinae and Trichomyiinae, among them Trichomyia dolichopogon sp. nov., T. riodocensis sp. nov. and 13 other species new to science but represented by females only. Twelve species of phlebotomine sand flies (Lutzomyia spp.) were also collected. Collections from an undisturbed area of the park were much richer faunistically than those from an area that was destroyed by fire in 1967 but had since regenerated, suggesting that recovery after environmental disturbances of this type may be prolonged. This pattern was not seen for phlebotomine sand flies, whose greater abundance and species richness in the disturbed section of the park may be related to their dependence on small mammal hosts, known to be more diverse in this type of habitat.
\end{abstract}

Key words: Psychodidae, Psychodinae, Trichomyiinae, Phlebotominae, Trichomyia dolichopogon sp. nov., T. riodocensis sp. nov., Atlantic Forest, indicator species.

\section{RESUMO}

\section{Algumas espécies de Psychodidae (Diptera) da Mata Atlântica no Sudeste do Brasil, com descrições de Trichomyia dolichopogon sp. nov. e Trichomyia riodocensis sp. nov.}

A família Psychodidae inclui além dos flebotomíneos de importância médica mais cinco subfamílias pouco estudadas no neotrópico. Os autores relatam os resultados de uma viagem para coletar psicodódeos no Parque Estadual do Rio Doce (Minas Gerais), o qual contém uma das maiores regiões sobreviventes da Mata Atlântica no Brasil. Amostragens realizadas mediante armadilhas Malaise e de luz (CDC), além de capturas em lugares de repouso diurno, incluíram 15 espécies de Psychodinae e Trichomyiinae, dentre elas Trichomyia dolichopogon sp. nov., T. riodocensis sp. nov. e mais 13 espécies novas à ciência, representadas apenas por fêmeas. Também foram coletadas 12 espécies de flebotomíneos (Lutzomyia spp.). As amostras da área do parque não atingida pelo fogo em 1967 tinham uma diversidade de espécies muito maior que as da área destruída e subseqüentemente regenerada, sugerindo que a recuperação após uma catástrofe ambiental desse tipo pode ser muito prolongada. Esse padrão não foi observado nos flebotomíneos, cuja maior abundância e riqueza de espécies na parte afetada do parque podem ser relacionadas a sua dependência por mamíferos pequenos, os quais atuam como hospedeiros e são os mais diversos neste tipo de ambiente.

Palavras-chave: Psychodidae, Psychodinae, Trichomyiinae, Phlebotominae, Trichomyia dolichopogon sp. nov., T. riodocensis sp. nov., Mata Atlântica, espécies indicadoras. 


\section{INTRODUCTION}

The family Psychodidae consists of five subfamilies (Bruchomyiinae, Phlebotominae, Psychodinae, Sycoracinae and Trichomyiinae) all of which are present in the Neotropics (Duckhouse, 1973; Young, 1979). Two members of the Psychodinae, Psychoda alternata Say and Clogmia albipunctata Enderlein have a worldwide distribution and have some public health significance. Populations of these insects may become a nuisance when they colonise water treatment plants, larvae and adults interfering with the processing of effluent and possibly acting as mechanical vectors of associated human pathogens and promoters of asthma (Forattini, 1973). The exclusively Neotropical members of the psychodid subfamilies other than the Phlebotominae had received relatively little attention until Quate (1996, 1999) began collections in South and Central America. It is clear from this work that these insects have been highly successful in the region, a rich variety of species having arisen in forested areas. Diminished numbers of genera and species in areas disturbed by man's activities indicate that the group may be a good indicator of the condition of tropical forests.

Phlebotomine sand flies are much better known due to the medical importance of some species as vectors of Leishmania. At least 195 species of the genus Lutzomyia occur in Brazil (Young \& Duncan, 1994), of which 18 were captured by Andrade Filho et al. (1997) in the municipality of Timóteo, located at the edge of Parque Estadual do Rio Doce. Two of these species ( $L u$. whitmani and $L u$. intermedia) are suspected vectors of $L e$. braziliensis in other parts of their ranges (Rangel et al., 1984; Ryan et al., 1987).

Atlantic forest formerly occurred all along the coast of Brazil, extending from the present-day states of Pernambuco in the North to Santa Catarina in the South and west to Paraguay. In spite of later efforts to promote colonisation of the interior, including the construction of Brasília, most of the Brazilian population still occupies a relatively narrow but immensely long strip of coastline. This has resulted in destruction of an estimated $95 \%$ of the Atlantic Forest since the arrival of Europeans in 1500. This habitat was never contiguous and remnants are scattered among several Brazilian states, currently occupying a total of about $142,000 \mathrm{~km}^{2}$.
The Parque Estadual do Rio Doce (42 $38^{\prime} 30^{\prime \prime}$ $48^{\circ} 28^{\prime} 18^{\prime \prime} \mathrm{W} ; 19^{\circ} 48^{\prime} 18^{\prime \prime}-19^{\circ} 29^{\prime} 24^{\prime \prime} \mathrm{S}$ ) is one of the largest areas of Atlantic Forest still remaining and includes 35,974 hectares lying at an altitude of 230$515 \mathrm{~m}$ above sea level. Andrade et al. (1997) defined 19 different vegetation types for the park, including primary forest that covers $8.35 \%$ of the park and includes hardwood tree species such as jequitibá (Cariniana estrellenis), açoita-cavalo (Luehea grandiflora) garapa (Apuleia leiocarpa), vinhático (Platymenia foliosa), sapucaia (Lecythis pisonis), jacarandá-da-baía (Dalbergia nigra), cutieira (Joannesia princeps) and bicuíba (Virola gardneri). These can reach over $30 \mathrm{~m}$ in height and a lower strata $(10-18 \mathrm{~m})$ is dominated by the palmito (Euterpe edulis). Medium secondary forest that developed after the forest fires of 1964 and 1967 covers $17.2 \%$ of the park area and currently has an closed understorey of bamboo, graminoids and lianas, with a medium stratum of $8-10 \mathrm{~m}$ characterised by brejaúba palms (Astrocarium aculeatissum) and an emergent canopy of 8-15 m dominated by Eschweilera sp. and angico-branco (Imperata brasiliensis). No information is available on the psychodid fauna of the park, other than the sampling survey carried out by Andrade Filho et al. (1997) in Timóteo. The principal objectives of the present study were to collect specimens of the subfamilies Psychodinae and Phlebotominae and compare the faunae of these groups in two sections of the park, one of which had been destroyed by fire in 1967 and subsequently regenerated while the other remained unaffected by human activities.

\section{MATERIAL AND METHODS}

All collections were made by the authors during May 1998. Small (3 m long) Malaise traps were placed in forest across areas thought to represent potential flyways for psychodids. A total of 6 such traps were left in place for 21 trap-nights in the southern section of the park, which had regenerated after being destroyed by fire 31 years before.

Malaise trapping was also carried out in the pristine northern section of the park, near the village of Cava Grande at approximately $45 \mathrm{~km}$ from the southern section. A total of five traps were left in place in the northern section during eight trap nights. All traps were revised daily between 13-18 May. Psychodids were sorted, preserved dry and 
subsequently cleared in lactophenol for examination under the microscope.

Up to six CDC light traps (Sudia \& Chamberlain, 1962) fitted with photocells were also hung in forest in the southern section between 1318 May. Three CDC traps were also hung in the northern section during the nights of 15-17 May. Sand flies that alit on the illuminated wall of the sleeping quarters in the southern section of the park were aspirated for approximately $1 \mathrm{~h}$ each night and a few specimens were also aspirated from the trunks and buttress roots of large trees encountered in the northern section. All sand flies were cleared in lactophenol and identified according to the keys of Young \& Duncan (1994).

\section{RESULTS}

Results of collections in the two sections of the park are summarised in Tables 1 and 2. Not counting the cosmopolitan species Psychoda alternata Say and Clogmia albipunctata Williston, a total of 35 individuals of 15 species of the subfamilies Psychodinae and Trichomyiinae were collected, belonging to five genera (Aleppo, Caenobrunnetia, Psychoda, Philosepedon and Trichomyia). Several examples belonging to the genus Trichomyia represented two new species that are formally described below. Females of 13 other undescribed species belonging to the genera Trichomyia (5), Alepia (2), Psychoda (4) and Caenobrunnetia (1) and Philosepedon (1), were also collected. Formal description of these species depends on male specimens being collected in the future.

\section{Genus Trichomyia Haliday:}

Trichomyia Haliday, 1839: 745; Quate, 1996: 5

Trichomyia riodocensis new species (Figs. 1 and 2) Distribution: Brazil (Minas Gerais, Rondônia) Male

Palpus four-segmented, suture between palpomeres 1 and 2 incomplete. Antennae incomplete, flagellomeres symmetrical. Gonocoxite with quadrate, knob-like protrusion on median dorsal surface at distal 1/3; subapically enlarged gonostylus tapers abruptly to a sharp, attenuate apex; basiphallus of aedeagus very short; distiphallus simple, expanded apically: surstylus elongate and triangular with one very long spine at distal $1 / 4$ and several anterior to it on dorsal margin; tergite 10 with convergent sides, rounded apex, length $1.5 \mathrm{X}$ width. Measurements (in $\mathrm{mm}$ ): wing length $1.38-1.53 \mathrm{~mm}$, width $0.53-0.68$ (means $=1.44$ and 0.59 , respectively, $\mathrm{n}=8$ ).

\section{Female}

Subgenital plate triangular, length slightly less than width, genital opening keyhole-shaped; pair of curved bars flanking opening; spermathecae large, leading into long, heavily annulated ducts originating in abdominal segment 6 or 7; cerci circular.

Measurements (in mm): antenna $1.07(\mathrm{n}=1)$; wing length 1.28-1.60; width 0.48-0.60 (means = 1.50 and 0.54 , respectively, $\mathrm{n}=11$ ).

Holotype male and allotype female of this species both from Parque Estadual do Rio Doce, Minas Gerais, Brazil (1948'S; 42³8'W). Malaise taps, 14-18.v.1998. All collections made by B. Alexander, L. Quate and J. M. Freitas.

Paratypes: 5 males, 14 females, same collecting data; 2 males, 1 female, Cacaulândia, Rondônia, $200 \mathrm{~km}$ SSE of Porto Velho (10 18 'S; $62^{\circ}$ 52'W) Malaise traps at 140 masl, 25.v.-6.vi.1998, collections by L. Quate.

Primary types will be deposited in the museum of the University of São Paulo.

T. riodocensis appears to be closely related to T. brevitarsis Rapp (Duckhouse, 1974; Quate, 1996). The genitalia of the two species are similar in many respects, especially the lobed gonocoxite and surstylus with an acute, attenuated apex. However in $T$. riodocensis the basiphallus is very short and the apex of the distiphallus is fluted, whereas in $T$. brevitarsis the former is very long (equal in length to the distiphallus) and the latter is elongate and tapering. In addition, the gonostylus is bifurcate and black at the apex in $T$. brevitarsis but plain and clear in T. riodocensis. Although T. brevitarsis has a wide geographical range (Costa Rica, Panama, Venezuela, Surinam and Peru) the female of this species is unknown.

Trichomyia dolichopogon, new species (Fig. 3) Male

Single row of large hair scars along inner ocular margin. Palpus with three palpomeres, ratio of palpomeres 10:7:6; palpomere 1 with sensilla in pit on inner margin.

Antenna with flagellomere one pyriform, remaining flagellomeres eccentric (terminal ones lacking); ascoid extends to centre of following flagellomere. 
Wing clear; length 2.7 times width; Sc extends beyond base of R4, crossvein sc-r well developed; $\mathrm{R} 2+3$ and $\mathrm{R} 2$ subequal in length; radial fork about two cell widths distad of medial; medial fork near centre of wing.

Anterior margin of tergite 7 a thin sclerotised band expanded at lateral margins; posterior margin with trifid sclerotised plate, three long, appressed, persistent hairs on lateral margins (may appear as one when closely appressed), straight but sharply recurved at apex, row of three or four hair scars extend medioanteriorly from large hairs.

Gonocoxite unmodified; gonostylus straight with dark, crenate lateral margin on apical half; surstylus triangular with rounded apex, hairy but without heavy bristles or spines. Measurements: wing length $1.69-1.93 \mathrm{~mm}$, width 0.63-0.92 mm.

\section{Female}

Although three females that undoubtedly belong to this species were collected during the present study, they were retrieved from the traps in poor condition and are considered to be unsuitable for designation as type specimens.

Holotype: Parque Estadual do Rio Doce, Minas Gerais (1943’S; 42³0’W) 14-18.v.1998.

Paratype: as above.

Etymology: Gr. dolichos = long, pogon $=$ beard, refers to long hairs on tergite 7 .

The holotype and allotype specimens will be deposited in the museum of the University of São Paulo.

This is the third species of a distinctive group marked by the three pairs of long hooked hairs on tergite 7 .

T. pedicillata Satchell (1956) occurs in Panama and T. dolichakis Quate (1996) is found in Costa Rica.

Other Neotropical species of this group are in the collection of one of the authors (LWQ) and await description.

TABLE 1

Numbers of psychodids (families Psychodinae and Trichomyiinae) collected in northern (pristine) and southern (regenerated) sections of Parque Estadual do Rio Doce, Minas Gerais, May 1998. All collected in Malaise traps only except ${ }^{*}$ collected in CDC light traps only.

\begin{tabular}{|c|c|c|c|}
\hline \multirow{2}{*}{ Family } & \multirow{2}{*}{ Species } & \multicolumn{2}{|c|}{ Section of park } \\
\hline & & North & South \\
\hline \multirow[t]{7}{*}{ Trichomyiinae } & Trichomyia riodocensis n. sp. & $4 \mathrm{M} 11 \mathrm{~F}$ & $1 \mathrm{M} 3 \mathrm{~F}$ \\
\hline & Trichomyia dolichopogon $\mathrm{n}$. sp. & $1 \mathrm{M} 3 \mathrm{~F}$ & $1 \mathrm{M}$ \\
\hline & Trichomyia n. sp. 2 & 0 & $1 \mathrm{~F}$ \\
\hline & Trichomyia n. sp. 3 & $1 \mathrm{~F}$ & $1 \mathrm{~F}$ \\
\hline & Trichomyia n. sp. 4 & $3 \mathrm{~F}$ & 0 \\
\hline & Trichomyia n. sp. 5 & $2 \mathrm{~F}$ & 0 \\
\hline & Trichomyia n. sp. 6 & $2 \mathrm{~F}$ & 0 \\
\hline \multirow[t]{8}{*}{ Psychodinae } & Psychoda n. sp. 1 & 0 & $1 \mathrm{~F}^{*}$ \\
\hline & Psychoda n. sp. 2 & 0 & $1 \mathrm{~F}^{*}$ \\
\hline & Psychoda n. sp. 3 & 0 & $1 \mathrm{~F}^{*}$ \\
\hline & Psychoda n. sp. 4 & 0 & $1 \mathrm{~F}^{*}$ \\
\hline & Caenobrunnetia $\mathrm{n} . \mathrm{sp}$. & $1 \mathrm{~F}$ & 0 \\
\hline & Alepia n. sp. 1 & $1 \mathrm{~F}$ & 0 \\
\hline & Alepia n. sp. 2 & $1 \mathrm{~F}$ & 0 \\
\hline & Philosepedon n. sp. & $1 \mathrm{~F}$ & 0 \\
\hline \multicolumn{2}{|l|}{ Total n. specimens } & 31 (10 spp.) & 11 (8 spp.) \\
\hline \multicolumn{2}{|c|}{ Mean n. specimens/trap-night (Malaise traps only) } & 3.37 & 0.33 \\
\hline
\end{tabular}

* Two other common species (Psychoda alternata and Clogmia albipunctata) were collected in large numbers at both sites and are not considered here. 
TABLE 2

Numbers of sand flies (subfamily Phlebotominae) collected in northern (pristine) and southern (regenerated) sections of Parque Estadual do Rio Doce, Minas Gerais, May 1998.

\begin{tabular}{|c|c|c|c|}
\hline \multirow{2}{*}{ Species } & \multirow{2}{*}{ Collecting method } & \multicolumn{2}{|c|}{ Section of park } \\
\hline & & North & South \\
\hline $\begin{array}{l}\text { Lutzomyia borgmeieri Martins, } \\
\text { Falcão \& Silva }\end{array}$ & $\begin{array}{l}\text { Aspiration from illuminated } \\
\text { wall/CDC light trap }\end{array}$ & 0 & $2 \mathrm{~F}$ \\
\hline \multirow{2}{*}{ L. davisi (Root) } & “ & 0 & $1 \mathrm{M} 11 \mathrm{~F}$ \\
\hline & Malaise trap & 0 & $1 \mathrm{M} 2 \mathrm{~F}$ \\
\hline L. fairchildi Barretto & CDC light trap & 0 & $1 \mathrm{~F}$ \\
\hline \multirow{2}{*}{ L. fischeri (Pinto) } & “ & 0 & $1 \mathrm{~F}$ \\
\hline & Aspiration from tree trunks & $2 \mathrm{~F}$ & 0 \\
\hline \multirow{3}{*}{ L. intermedia (Lutz \& Neiva) } & “ & $4 \mathrm{M} 3 \mathrm{~F}$ & 0 \\
\hline & Malaise trap & $2 \mathrm{M}$ & 0 \\
\hline & $\begin{array}{l}\text { Aspiration from illuminated } \\
\text { wall/CDC light trap }\end{array}$ & 0 & $38 \mathrm{M} 21 \mathrm{~F}$ \\
\hline \multirow{2}{*}{ L. longispina (Mangabeira) } & \multirow{2}{*}{ “ } & 0 & $3 \mathrm{M}$ \\
\hline & & 0 & $2 \mathrm{M}$ \\
\hline L. lutziana (Costa Lima) & $\begin{array}{l}\text { Aspiration from illuminated } \\
\text { wall/CDC light trap }\end{array}$ & 0 & $1 \mathrm{~F}$ \\
\hline L. misionensis (Castro) & “ & 0 & $1 \mathrm{M} 4 \mathrm{~F}$ \\
\hline \multirow{2}{*}{ L. sallesi (Galvão \& Coutinho) } & “ & 0 & $2 \mathrm{~F}$ \\
\hline & Malaise trap & 0 & $1 \mathrm{~F}$ \\
\hline \multirow[t]{3}{*}{ L. schreiberi Martins, Falcão \& Silva } & “ & $3 \mathrm{M} 16 \mathrm{~F}$ & 0 \\
\hline & $\begin{array}{l}\text { Aspiration from illuminated } \\
\text { wall/CDC light trap }\end{array}$ & 0 & $3 \mathrm{~F}$ \\
\hline & Aspiration from tree trunks & $1 \mathrm{M} \mathrm{3F}$ & 0 \\
\hline \multirow[b]{2}{*}{ L. sordellii (Shannon \& Del Ponte) } & Malaise trap & 0 & $1 \mathrm{~F}$ \\
\hline & $\begin{array}{l}\text { Aspiration from illuminated } \\
\text { wall/CDC light trap }\end{array}$ & 0 & $4 \mathrm{~F}$ \\
\hline L. walkeri (Newstead) & “ & 0 & $1 \mathrm{M} 1 \mathrm{~F}$ \\
\hline \multicolumn{2}{|l|}{ Totals } & 34 (3 spp.) & 102 (12 spp.) \\
\hline \multicolumn{2}{|l|}{ Mean n./trap night (Malaise traps only) ${ }^{\mathbf{a}}$} & 2.62 (2 spp.) & 0.24 (3 spp.) \\
\hline
\end{tabular}

${ }^{a}$ Mean $n$. of insects per unit time cannot be compared for other sampling methods, since collections off illuminated walls were made only in southern section and off tree trunks only in northern section.

While males of each species bear hooked hairs on the seventh tergite, the genitalia are distinct. Small spermathecae with very short ducts and double anchor-like sclerites between the spermathecae (as seen in both $T$. pedicillata and T. dolichakis) may prove to be the group characters for the females.

Five other species of Trichomyia were collected at Rio Doce but since four of these are represented only by females formal description should await the discovery of associated males.

\section{Genus Alepia Enderlein}

Alepia Enderlein, 1937: 94; Quate, 1996: 20

Two females of Alepia were collected in Malaise traps in the northern section of the park.

Although neither can be identified they appear to belong to two undescribed species. 

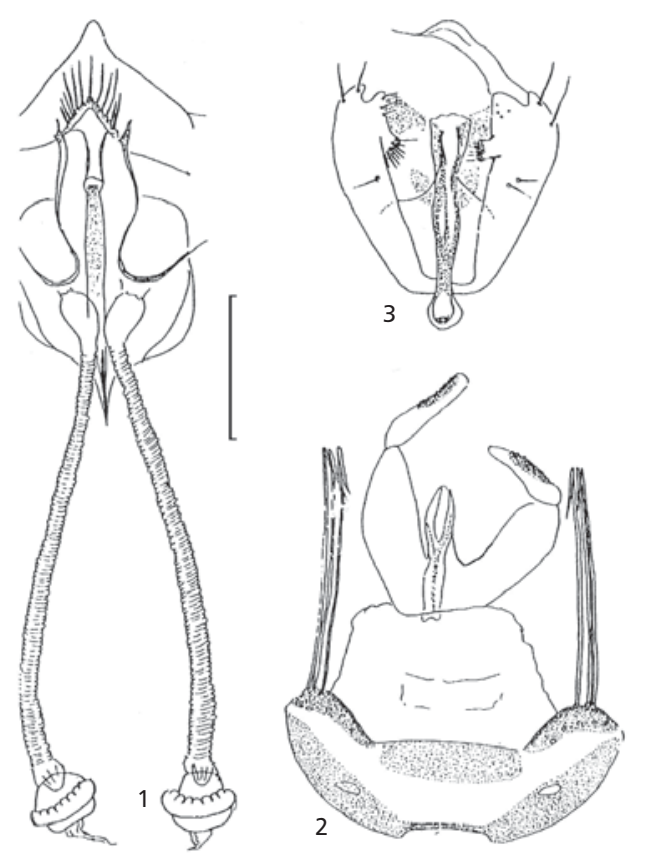

Figs. 1-2 - Numbers of sand flies (subfamily Phlebotominae) collected in northern (pristine) and southern (regenerated) sections of Parque Estadual do Rio Doce, Minas Gerais, May 1998. Fig. 3 - Trichomyia dolichopogon sp. nov. Gonopods, aedeagus, tergites 7 and 8 . Scale line $=0.1 \mathrm{~mm}$.

Genus Caenobrunnetia Wagner

Caenobrunnetia Wagner, 1981: 218;

Quate, 1996: 25

One female of an undescribed species was collected in a Malaise trap in the northern section of the park. Naming this species again must await discovery of associated males.

\section{Genus Psychoda Latreille}

Psychoda Latreille, 1796: 152; Quate, 1996: 60

Four species of Psychoda were collected in a light trap in the southern section of the park. Each is represented by a single female and formal description should be deferred until larger series are available, including associated males.

\section{Genus Philosepedon}

Philosepedon Eaton, 1904: 55

One female of an undescribed Philosepedon species was collected in a Malaise trap in the northern section of the park. Again formal description should be deferred until more specimens are collected.

\section{Genus Lutzomyia Franca}

Twelve species of phlebotomine sand flies (Lutzomyia spp.) were collected (Table 2). Nine of these had previously been collected using CDC light traps in the municipality of Timóteo (Andrade Filho et al., 1997). The three new records are discussed below.

\section{Lutzomyia (Micropygomyia) schreiberi Martins, Falcão \& Silva 1975}

This species closely resembles $L$. (M.) micropyga (Mangabeira) and according to Martins et al. (1975), replaces it outside Amazonian Brazil. It is somewhat larger than L. (M.) micropyga and differs in the pigmentation of the thorax, relative size of profemur and protibia and the arrangement of the distal spines of the basistyle. Sherlock \& Pessoa (1966) found $3.3 \%$ of 368 females (misidentified as L. micropyga) that they dissected to be infected with flagellates, perhaps parasites of geckoes.

\section{L. (Psychodopygus) fairchildi Barretto 1966}

Although there are no published records of this species in Minas Gerais since it has been collected from the neighbouring states of Rio de Janeiro and Espírito Santo (Martins et al., 1978) its presence in Parque Estadual do Rio Doce does not represent a significant extension of its known range. There is one unpublished record of L. fairchildi 
in the Atlantic Forest of Minas Gerais, Dr. P. Williams having collected a male and two females at Fazenda Montes Claros, municipality of Caratinga.

\section{L. walkeri (Newstead 1914)}

This species has a wide geographical range, extending from Panama to central Paraguay. In Minas Gerais it has already been recorded from the muncipality of Arinos (Martins et al., 1978), lying $510 \mathrm{~km}$ northeast of P. E. Rio Doce.

\section{DISCUSSION}

The southern section of Parque Estadual do Rio Doce was devastated by fires that destroyed 9,000 hectares of Atlantic Forest in July-September 1967, equivalent to $25 \%$ of the park's present area. In May 1998 the forest appeared to have regenerated and superficially resembled the northern section of the park, which was not affected. Two other serious fires in 1964 and 1993 destroyed 3,000 and 1,000 ha. respectively, the latter occurring in five separate parts of the park. Apparent differences in the psychodid fauna between the two sections indicated that regeneration of the damaged section was not complete. Malaise traps run in the two sections occupied similar sites but those in the south collected only seven specimens, representing four species of the genus Trichomyia, in 21 trap nights. A further four specimens, each representing an undescribed species of the genus Psychoda, were collected in CDC light traps hung the southern section. In the north a total of 31 specimens of 10 species belonging to the genera Trichomyia, Caenobrunnetia, Alepia and Philosepedon were collected in only eight trap nights. Although these data are based on collections made over a very short period, the striking difference in the number of specimens collected per trap-night in the northern and southern sections (3.87 vs. 0.33 ) indicates that insufficient time had elapsed since the destruction of the latter for it to recover its full diversity of psychodids.

Malaise traps only collected six phlebotomine sand fly species, four of these (Lu. sallesi, Lu. davisi, Lu. longispina and Lu. sordellii in the south and two (Lu. intermedia and Lu. schreiberi) in the north. All twelve of the Lutzomyia species collected in P. E. Rio Doce were however represented in our collections from the southern section and only three were found in the northern part, $L u$. fischeri being collected by direct aspiration from tree trunks, together with the species already mentioned. The smaller number of specimens caught in Malaise traps in the southern section notwithstanding, results of sand fly sampling do not permit the same conclusions to be drawn from comparisons of collections made in the two areas of the park as for other psychodids. There are however at least two fundamental biological differences between the two groups of insects: phlebotomine sand flies are blood-feeders that breed in terrestrial rather than aquatic microhabitats. According to Forattini (1973) the Trichomyiinae have, like Phlebotominae, become secondarily adapted to breeding in terrestrial habitats. The latter have been able to colonise arid regions, particularly in the Old World. Although members of the genus Psychoda are highly adaptable, most neotropical psychodines are linked with primitive niches such as the vicinity of streams and many (particularly members of the genera Caenobrunettia and Alepia) quickly disappear when these habitats are disturbed (Quate, unpublished observations). One way in which the less mature habitats such as the southern section of P. E. Rio Doce may permit greater species richness of phlebotomines is through the dependence of these insects on their hosts for blood meals. Small mammal species diversity and population densities of these species may increase in disturbed habitats and the presence of certain rodent and opossum species may indicate a habitat in decline (Malcolm, 1991; Adler et al., 1997a, 1997b). Dorvillé (1996) carried out an analysis of mosquito collections in SE Brazil and suggested that as obligate blood feeders dependent on vertebrate these insects would be particularly useful as indicators of forest quality. The same argument has been be put forward for phlebotomine sand flies (Barrett et al., 1996) and studies of this type could illustrate both the public health and environmental consequences of human activities such as deforestation and reforestation with exotic tree species.

While conclusions on the usefulness of psychodids as indicators of habitat quality must be made with caution due to the brief time devoted to sampling during this study, it is hoped that the results presented here will stimulate further study. At least 13 species are present in Parque Estadual do Rio Doce that would require additional collec- 
tions to allow formal description and it is likely that several other undescribed members of this family are present in the Atlantic Forest of SE Brazil.

Acknowledgments - To Sânzia Romanova Duarte Ferreira da Silva Nunes and Mário Izumi Utino for logistic assistance at Parque Estadual do Rio Doce and to Alda Lima Falcão and Jose Dilermando Andrade for assistance with identification of sand flies. The senior author was supported by a visiting researcher grant from $\mathrm{CNPq}$.

\section{REFERENCES}

ADLER, G. H., ARBOlEDA, J. J. \& TRAVI, B. L. 1997a, Diversity and abundance of small mammals in degraded tropical dry forest of Northern Colombia. Mammalia, 61: 361-370.

ADLER, G. H., ARBOLEDA, J. J. \& TRAVI, B. L., 1997b, Population dynamics of Didelphis marsupialis in Northern Colombia. Stud. Neotrop. Fauna \& Environ., 32: 7-11.

ANDRADE, P. M. de, PEREIRA, M. C. A. \& da COSTA E SILVA, L. V., 1997, The vegetation of Rio Doce State Park, pp. 15-21. In: J. G. Tundisi \& Y. Saijo (eds.), Limnological Studies of the Rio Doce Valley Lakes, Brazil. Brazilian Academy of Sciences, São Paulo.

ANDRADE FILHO, J. D., CARNEIRO, A. P. S., LIMA, M. L. N., SANTIAGO, R. M., GAMA, M. A., SANTOS, C. A., FALCÃO, A. L. \& BRAZIL, R. P., 1997, Flebotomíneos de Timóteo, Estado de Minas Gerais, Brasil (Diptera: Psychodidae). Cad. Saúde Pública, 13: 767-770.

BARRETT, T. V., DE FREITAS, R. A., ALBUQUERQUE, M. I. C. \& GUERRERO, J. H. C., 1996, Report on a collection of Lutzomyia sand flies (Diptera: Psychodidae) from the Middle Solimões (Amazonas, Brazil). Mem. Inst. Oswaldo Cruz, 91: 27-35.

DORVILLÉ, L. F. M., 1996, Mosquitoes as bioindicators of forest degradation in South-eastern Brazil, a statistical evaluation of published data in the literature. Stud. Neotrop. Fauna \& Environ., 31: 68-78.

DUCKHOUSE, D. A., 1973, A catalogue of the Diptera of the Americas South of the United States. 6A Family Psychodidae, subfamilies Bruchomyiinae, Trichomyiinae, Sycoracinae and Psychodinae. Mus. Zool. Univ. São Paulo, 29p.

DUCKHOUSE, D. A., 1974, Redescription of the Neotropical Psychodidae (Diptera, Nematocera) described by Rapp and Curran. J. Entomol., 43: 55-62.

EATON, A. E., 1904, New genera of European Psychodidae. Entomol. Monthly Mag., 2(15): 55-59.

ENDERLEIN, G., 1937, Klassification der Psychodiden (Dipt.). Deutsche Entomol. Zeit., 1936: 81-112.

FORATTINI, O. P., 1973, Entomologia Médica. Vol. 4 Psychodidae. Phlebotominae. Leishmanioses. Bartonelose. Edgard Blucher, São Paulo, 658p.
MALCOLM, J. R., 1991, Comparative abundances of neotropical small mammals by trap height. $J$. Mammalol., 72: 188-192.

MARTINS, A. V., FALCÃO, A. L. \& DA SILVA, J. E., 1975, Lutzomyia schreiberi n. sp., nova espécie de flebotomíneo afim de Lutzomyia micropyga (Mangabeira, 1942), (Diptera, Psychodidae, Phlebotomidae). Ciência e Cultura, 27: 766-772.

MARTINS, A. V., WILliamS, P. \& FALCÃO, A. L., 1978, American Sand Flies (Diptera: Psychodidae: Phlebotominae). Academia Brasileira de Ciências, Rio de Janeiro, 195p.

QUATE, L. W., 1996, Preliminary taxonomy of Costa Rican Psychodidae (Diptera), exclusive of Phlebotominae. Rev. Biol. Trop., 44: 1-81.

QUATE, L. W., 1999, Taxonomy of Neotropical Psychodidae (Diptera) 3. Psychodines of Barro Colorado Island and San Blas, Panama. pp. 409-441. In: Memoirs on Entomology, International. Vol. 14. Contributions to the Knowledge of Diptera: a Collection of Articles on Diptera Commemorating the Life and Work of Graham B. Fairchild. Associated Publishers, Gainesville, FL, $648 \mathrm{p}$.

RANGEL, E. F., SOUZA, N. A., WERMELINGER, E. D. \& BARBOSA, A. F., 1984, Infeção natural de Lutzomyia intermedia (Lutz \& Neiva, 1912) em área endêmica de leishmaniose tegumentar no Estado do Rio de Janeiro. Mem. Inst. Oswaldo Cruz, 80: 373-374.

RYAN, L., LAINSON, R. \& SHAW, J. J., 1987, Leishmaniasis in Brazil. XXIV. Natural flagellate infections of sandflies (Diptera: Psychodidae) in Pará State, with particular reference to the role of Psychodopygus wellcomei as the vector of Leishmania braziliensis braziliensis in the Serra dos Carajás. Trans. R. Soc. Trop. Med. Hyg., 81: 353-359.

SATCHELL, G. H., 1956, On the genus Trichomyia Haliday (Diptera: Psychodidae) with descriptions of four new species. Proc. R. Entomol. Soc. London (B), 25: 147156.

SHERLOCK, I. \& PESSOA, S. B., 1966, Leptomonas infectando naturalmente Phlebotomus em Salvador (Bahia, Brasil). Rev. Lat. Am. Microbiol., 8: 47-50.

SUDIA, W. D. \& CHAMBERLAIN, R. W., 1962, Battery light trap, an improved model. Mosquito News, 22: 126-129.

WAGNER, R., 1981, Two moth-flies (Diptera, Psychodidae) from South America. Studies Neotrop. Fauna Environ., 16: 217-220.

YOUNG, D. G., 1979, A review of the bloodsucking psychodid flies of Colombia (Diptera: Phlebotominae and Sycoracinae). Agricultural Exp. Stations Bull. 806 (technical). Institute of Food and Agricultural Sciences, University of Florida, Gainesville, 266p.

YOUNG, D. G. \& DUNCAN, M. A., 1994, Guide to the Identification and Geographic Distribution of Lutzomyia Sand Flies in Mexico, the West Indies, Central and South America (Diptera: Psychodidae). Mem. Am. Entomol. Inst., 54: 1-881. 